\title{
Alarm Device
}

National Cancer Institute

\section{Source}

National Cancer Institute. Alarm Device. NCI Thesaurus. Code C49813.

A device designed to signal the occurrence of a particular event. 